\title{
Field response of Hylastinus obscurus Marsham (Coleoptera: Curculionidae) to E-2-hexenal and limonene, two host-derived semiochemicals
}

\author{
Leonardo Parra ${ }^{1}$, Ana Mutis ${ }^{1}$, Fernando Ortega $^{2}$, and Andrés Quiroz ${ }^{1}$ \\ ${ }^{1}$ Departamento de Ciencias Químicas y Recursos Naturales, Universidad de La Frontera, Temuco, Chile, \\ Casilla 54-D. \\ ${ }^{2}$ Instituto de Investigaciones Agropecuarias, INIA Carillanca, Chile, Casilla 58-D.
}

\begin{abstract}
L. Parra, A. Mutis, F. Ortega, and A. Quiroz. 2013. Field response of Hylastinus obscurus Marsham (Coleoptera: Curculionidae) to $E$-2-hexenal and limonene, two host-derived semiochemicals. Cien. Inv. Agr. 40(3): 637-642. Red clover (Trifolium pratense L.), a valuable legume in Chile, is important mainly for seed production and as forage for animal production. Although it is considered a perennial, the productivity of this legume declines during the second year of growth primarily because of infestation by the red clover root borer, Hylastinus obscurus (Coleoptera: Curculionidae). Currently, there is no efficient method for controlling this insect, although the use of semiochemicals may provide a new alternative to reduce the damage caused by this curculionid. In this context, E-2-hexenal and limonene, which were previously determined to be an attractant and a repellent, respectively, for $H$. obscurus, were released from dispensers established in two cultivars (Quiñequeli INIA and Superqueli INIA) and one experimental line (Syn II Pre III) of red clover at the Centro Regional de Investigación Carillanca (INIA-Carillanca) (Vilcún, Chile). H. obscurus was found in significantly higher numbers on plants from areas treated with $E$-2-hexenal than from areas treated with limonene or in areas that were left untreated as control areas. However, this attractiveness was influenced by the red clover source such that the effect of $E$-2-hexenal was observed in Superqueli INIA and Syn II Pre III but not in Quiñequeli INIA. Unlike previous studies, limonene had no effect on $H$. obscurus. Our results provide the first evidence under field conditions for the potential use of E-2-hexenal as an attractant for the red clover root borer H. obscurus.
\end{abstract}

Key words: E-2-hexenal, Hylastinus obscurus, limonene, semiochemicals, Trifolium pratense.

\section{Introduction}

Red clover (Trifolium pratense L.) is a valuable forage legume in temperate regions of the world. This species is characterized by its adaptation to a wide range of soil types, $\mathrm{pH}$ levels, and envi-

Received March 16, 2013. Accepted August 7, 2013. Corresponding author: andres.quiroz@ufrontera.cl ronmental and management conditions (Steiner and Alderman, 2003). In Chile, this legume is an important resource for the seed industry as well as for animal production and is used primarily in short-rotation pastures and as hay, silage and soiling (Ortega et al., 2012). Although it is considered a perennial plant, several authors have reported that $T$. pratense yields decline dramati- 
cally after two years because of high mortality (Steiner and Alderman, 2003). The principal factor contributing to this yield reduction is infestation by the red clover root borer, Hylastinus obscurus (Marsham) (Coleoptera: Curculionidae) (Steiner and Alderman, 2003). This curculionid causes a significant reduction in the production levels and the persistence of red clover fields because both the larvae and adults bore and feed within the roots (Aguilera et al., 1996). Pesticides have not successfully controlled H. obscurus infestations (Aguilera et al., 1996); therefore, alternative strategies for controlling this insect are necessary. In this regard, the role of semiochemicals (volatile compounds) released from the red clover plants in eliciting behavioral responses from adult $H$. obscurus has been investigated. In a previous study, Kamm and Buttery (1984) determined the preference of root borers for extracts obtained from roots of diseased red clover plants and for volatile compounds identified in these extracts, such as methyl salicylate. Tapia et al. (2005) reported that $H$. obscurus does not discriminate between volatiles released from an ethanolic extract obtained from healthy red clover roots and those from roots infected with Fusarium oxysporum Schlecht. Quiroz et al. (2005) reported that volatiles from the aboveground parts of red clover elicited changes in the behavior of H. obscurus according to plant age. The insects preferred extracts from young (1.5-yr-old) plants over extracts from 2.5-yr-old plants. In another study performed with root extracts from 1.5 - and 2.5-yr-old plants, Tapia et al. (2007) determined that the curculionid is attracted to root volatiles of 1.5- but not 2.5-yr-old plants. In both root extracts, 11 compounds were identified, but only $E$-2-hexenal and methyl benzoate attracted $H$. obscurus in olfactometric bioassays. By contrast, limonene repelled the insects, and an increase in the limonene content along with a decrease in the E-2-hexenal content was associated with a loss of attractiveness of the 2.5-yr-old clover roots (Tapia et al., 2007). Alarcón et al. (2010) determined that the Quiñequeli INIA cultivar was susceptible to $H$. obscurus, whereas the Superqueli INIA cultivar and the experimental Syn II Pre III line showed a lower H. obscurus abundance and a higher red clover forage yield.

There are many benefits to suggest that semiochemicals (used for behavioral control) are ideal components for use in integrated pest management (IPM) programs, including the following: 1) a low risk to human health and the environment compared with insecticides, 2) long-distance effectiveness because of their high volatility, and 3) usage generally at the same concentrations as those found in nature. For these reasons, studies are needed to provide a more complete understanding of the use of semiochemicals under field conditions for developing behavioral methods to control H. obscurus. Therefore, the objectives of this study were to evaluate the effects of $E$-2-hexenal and limonene on the density of $H$. obscurus under field conditions and to investigate the behavioral response of this insect toward two cultivars and one experimental line of $T$. pratense.

\section{Materials and methods}

\section{Location of the research and experimental design}

The red clover experimental plots were established in the spring of 2011 at the Instituto de Investigaciones Agropecuarias (INIA) Centro Regional de Investigación Carillanca ( $38^{\circ} 41 \square$ south latitude, $72^{\circ} 25 \square$ west longitude and 200 m.a.s.1.), located in the region of La Araucanía (Vilcún, Chile). The Quiñequeli INIA and Superqueli INIA cultivars and the Syn II Pre III experimental line were sown in previously prepared soil (Andisol, belonging to the series Vilcún, Temuco family) on September 28 using a Planet Junior manual seeder (Cole Planter Company, model B91-92B, Albany, GA, USA) at a seeding rate of $15 \mathrm{~kg} \mathrm{ha}^{-1}$. The separation between rows was $20 \mathrm{~cm}$. The cultivars and experimental line were arranged in a randomized complete block spatial layout with three 
replicates and a plot size of $7 \times 9 \mathrm{~m}$ each. Fertilization consisted of $150 \mathrm{~kg}$ of $\mathrm{P}_{2} \mathrm{O}_{5}$ ha $^{-1}$ and $100 \mathrm{~kg}$ of $\mathrm{K}_{2} \mathrm{O}$ ha- ${ }^{-1}$ and was based on $\mathrm{P}_{2} \mathrm{O}_{5}$, $\mathrm{K}_{2} \mathrm{O}, \mathrm{B}, \mathrm{S}$ and $\mathrm{Mg}$. No herbicides were applied because weed control was performed manually.

\section{Chemicals}

The following pure synthetic compounds used in the field experiments were purchased from Sigma Aldrich: $E$-2-hexenal ( $\geq 95 \%$, SAFC Sigma-Aldrich, St. Louis, Mo, USA) and limonene (mixture of isomers, 96\%, Sigma Aldrich Chemie Gmbh, Steinheim, Germany).

\section{Field test dispenser}

The field experiments were conducted between January 2012 and February 2013 at the INIA Carillanca. A split plot design with three replicates was used. The main plot $(7 \times 9 \mathrm{~m})$ was the semiochemical treatment, and the subplot $(7 \times 3 \mathrm{~m})$ was the red clover variety (average of 97 plants $\mathrm{m}^{-2}$ ). To avoid interaction among the semiochemical treatments, a distance of $10 \mathrm{~m}$ between the main plots was used. There were nine main plots: dispensers were deployed in all of these plots, but the dispensers released the attractant (E-2-hexenal), the repellent (limonene) or no semiochemical (as the control), with each treatment placed in three plots. The dispensers consisted of red rubber septa $(10 \mathrm{~mm})$ (SigmaAldrich, Steinheim, Germany), which were placed $20 \mathrm{~cm}$ above the ground on iron stakes A-44 (1.20 m long $\times 8 \mathrm{~mm}$ diameter) (Compañia de Acero del Pacífico S.A., Chile). Fifteen dispensers were placed in each main plot, with five in each subplot, for a total of 135 dispensers in the entire experiment. Before use, the dispensers were washed with solvent (dichloromethane) for $24 \mathrm{~h}$ and then dried under an extractor for $48 \mathrm{~h}$. The septa were loaded with $50 \mu \mathrm{L}$ of pure semiochemical and were recharged every seven days.

\section{Evaluation of $H$. obscurus infestation}

The evaluation of the red clover root borer population density was performed monthly from September 2012 to February 2013. Five plants of Quiñequeli INIA, Superqueli INIA and Syn II Pre III were randomly collected from each subplot in the field. The subterranean and aerial parts of each plant were separated, isolated in paper bags and transported to the laboratory. The different curculionid stages were gently removed from the roots using tweezers and transferred to Eppendorf tubes.

\section{Data analysis}

H. obscurus numbers by red clover variety and semiochemical treatment were analyzed with the Friedman test followed by the Conover-Inman test using StatsDirect statistical software v. 2.7.8 (StatsDirect Ltd., UK).

\section{Results}

Figure 1 presents the number of H. obscurus counted in each red clover variety. Although Superqueli INIA and Syn II Pre III showed higher numbers (100 and 87, respectively) than that shown by Quiñequeli INIA (30), this difference was not statistically significant $(\mathrm{P}=0.90)$. There were, however, more root borers in Superqueli INIA plots $(\mathrm{P}=0.004)$ and Syn II Pre III plots $(\mathrm{P}=0.03)$ baited with $E$-2-hexenal than in the respective plots treated with limonene or no semiochemical (Figure 1). The red clover root borer showed no preference for any semiochemical treatment in the Quiñequeli INIA cultivar $(\mathrm{P}=0.84)$.

During the evaluation period (January 2012 to February 2013), we captured a total of 217 red clover root borer individuals. Regardless of the cultivar or experimental line, the plots treated with $E$-2-hexenal attracted significantly $(\mathrm{P}=0.002)$ 


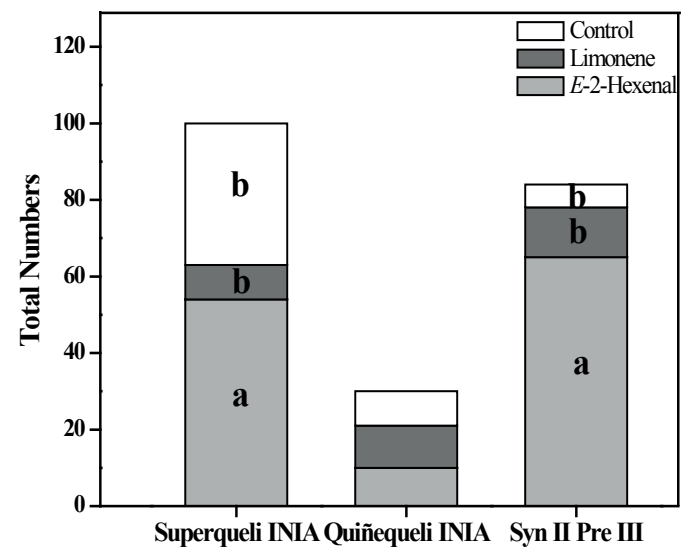

Figure 1. Numbers of $H$. obscurus in different cultivars and an experimental line of red clover subjected to different semiochemical treatments (E-2-hexenal, limonene and control) in INIA Carillanca (Vilcún, Chile) from September 2012 to February 2013. Different letters indicate a significant difference among treatments and control based on the Friedman test followed by the Conover-Inman test $(\mathrm{P} \leq 0.05)$.

more borers than those baited with limonene (Figure 2). There were no significant differences between the control plots and those treated with limonene $(\mathrm{P}=0.69)$ (Figure 2$)$.

\section{Discussion}

Our current field experiment and previous laboratory studies conducted by our group (Tapia et al., 2007; Palma et al., 2012) indicated the effectiveness of $E$-2-hexenal as an attractant for H. obscurus.

$E$-2-hexenal is a green leaf volatile that is present in different types of trees and serves as an attractant for bark beetles. For example, Vrko $\square$ ová et al. (2000) reported the attraction of Scolytus intricatus Ratzeburg towards E-2-hexenal, a volatile released from its host oak (Quercus robur L.). Palma et al. (2012) reported that in electroantennographic bioassays, H. obscurus showed a strong response to E-2-hexenal, which was associated with significant attraction in olfactometric bioassays.

More H. obscurus were observed on the E2-hexenal-treated plants of the Superqueli INIA

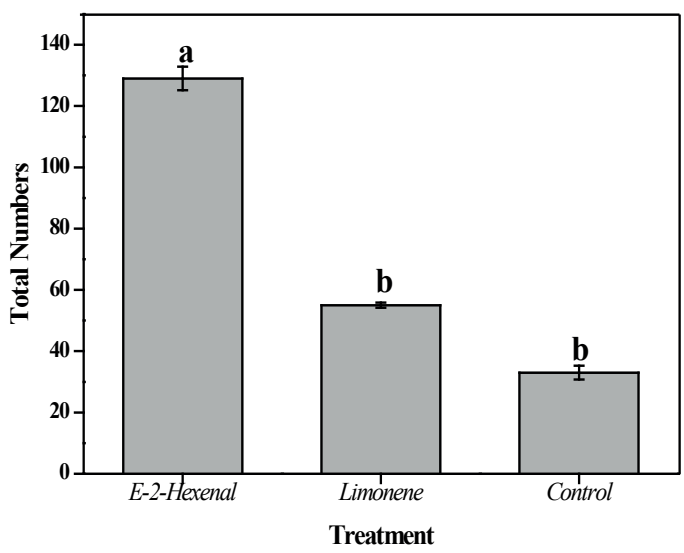

Figure 2. Total numbers of $H$. obscurus in Trifolium pratense subjected to different semiochemical treatments (E-2-hexenal, limonene and control) applied in a slowrelease dispenser at INIA Carillanca (Vilcún, Chile) from September 2012 to February 2013. Different letters indicate significant differences based on the Friedman test followed by the Conover-Inman test $(\mathrm{P} \leq 0.05)$.

cultivar and the Syn II Pre III experimental line (Figure 2). Our results do not agree with those reported by Alarcón et al. (2010), who showed a lower abundance of this curculionid and a higher red clover forage yield for Superqueli INIA and Syn II Pre III. One possible explanation is that the authors of this previous study evaluated the population dynamics of $H$. obscurus and their potential influence on the selection of new cultivars through agronomic parameters, such as dry matter, plants $\mathrm{m}^{-2}$ and root crown, but did not evaluate the effects of semiochemicals on the curculionid.

Although significantly fewer $H$. obscurus adults were attracted by $E$-2-hexenal than by limonene in the present study, the response to limonene did not differ significantly from that to the control (Figure 1 and 2). This behavior disagrees with that reported by Tapia et al. (2007), who detected a repellent effect of limonene on $H$. obscurus under laboratory conditions. A possible explanation for our field observations is that the volatile concentration applied was insufficient to modify the behavioral response of $H$. obscurus, which is consistent with the results of Bhasin et al. (2000) for other insects. 
Integrated pest management (IPM) and integrated crop management (ICM), the main concepts in managing pests, are related to the development of an environmentally friendly agriculture. Under IPM, semiochemicals are used to monitor pest populations as well as for mass trapping and mating disruption (Campion et al., 1985). Examples of semiochemicals for pest control have been reported by various authors, including the development of semiochemical-based tools to protect trees from bark beetle infestations using mainly antiaggregation and aggregation pheromones (Fettig et al., 2012). Gillette et al. (2009) indicated that the objective is to attract, retain and later destroy the pest. Moreover, the use of antiaggregation pheromones can reduce host finding by the pest and thus prevent successful colonization of the host.

In summary, our study provides the first evidence supporting the use of E-2-hexenal in the IPM of
H. obscurus and indicates the potential of using dispensers with $E$-2-hexenal under field conditions for trapping or monitoring applications. Several studies of traps baited with attractant semiochemicals to control curculionid pests have produced satisfactory results, especially with the curculionids Rhynchophorus palmarum L. and Scyphophorus acupunctatus Gyllenhal (Valdés et al., 2005). However, future research is required to study the feasibility of using $E$-2-hexenal to reduce $H$. obscurus populations below the economic threshold and as a part of an IPM program in red clover in Chile.

\section{Acknowledgements}

Andrés Quiroz thanks the Projects FONDECYT 1100812 and 11130715 for the funding that made this research possible.

\section{Resumen}

L. Parra, A. Mutis, F. Ortega y A. Quiroz. 2013. Respuesta de Hylastinus obscurus Marsham (Coleoptera: Curculionidae) a $E$-2-hexenal y limoneno, dos semioquímicos derivados de su hospedero, en condiciones de campo. Cien. Inv. Agr. 40(3): 637-642. El trébol rosado es una valiosa leguminosa, cuya importancia en Chile radica principalmente en la producción de semillas y su uso como alimento forrajero. A pesar de ser una planta perenne, su producción declina durante el segundo año de establecida, debido principalmente a la infestación del barrenador de la raíz del trébol Hylastinus obscurus (Coleoptera: Curculionidae). Actualmente no existe un método de control eficiente contra este insecto, por lo tanto, el uso de semioquímicos surge como una nueva alternativa para disminuir los daños ocasionados por este curculiónido. En este contexto, E-2-hexenal y limoneno, determinados previamente como atrayente y repelente a $H$. obscurus, fueron dispuestos en dispensadores de liberación lenta establecidas en dos cultivares y una línea experimental de trébol rosado en Centro de Investigación INIA Carillanca (Vilcún, Chile). Las evaluaciones indican que H. obscurus fue significativamente encontrado en mayor proporción en plantas sometidas al tratamiento con E-2-hexenal, comparadas con limoneno y el control. Sin embargo, este efecto atrayente fue influenciado por los cultivares y línea experimental de trébol rosado, de tal manera que el efecto de $E$-2-hexenal fue observado en Superqueli INIA y Syn II Pre III, pero no en Quiñequeli INIA. En contraste a previos estudios, limoneno no tuvo efecto sobre H. obscurus. Nuestros resultados permiten establecer la primera evidencia bajo condiciones de campo del potencial uso, especialmente E-2-hexenal, como un atrayente para H. obscurus.

Palabras clave: E-2-hexenal, Hylastinus obscurus, limoneno, semioquímicos, Trifolium pratense. 


\section{References}

Aguilera, A., E. Cisternas, M. Gerding, and H. Norambuena. 1996. Plagas de las praderas. In: I. Ruiz (ed.). Praderas para Chile. Segunda edición. Instituto de Investigaciones Agropecuarias INIA, Ministerio de Agricultura. Santiago, Chile. p. 309-339.

Alarcón, D., F. Ortega, F. Perich, F. Pardo, L. Parra, and A. Quiroz. 2010. Hylastinus obscurus (Marsham) and the yield of cultivars and experimental lines of red clover (Trifolium pratense L.). R.C. Suelo Nutr. Veg. 10: 115-125.

Bhasin, A., A.J. Mordue, and W. Mordue. 2000. Electrophysiological and behavioral identification of host kairomones as olfactory cues for $\mathrm{Cu}$ licoides impuntatus and C. nubeculosis. Physiol. Entomol. 25: 6-16.

Campion, D.G., B.R. Critchley, and L.J. McVeigh. 1985. Mating disruption. In: A. Jutsum, and R. Gordon (eds.). Insect Pheromones in Plant Protection. Wiley. New York. p. 89-119.

Fettig, C., S. McKelvey, C. Dabney, and D. Huber. 2012. Responses of Dentroctonus brevicornis (Coleoptera: Curculionidae) in behavioral assays: implications to development of a semiochemicals-based tool for tree protection. J. Econ. Entomol. 105: 149-160.

Gillette, N.E., C.J. Mehmel, J.N. Webster, S.R. Mori, N. Erbilgin, D.L. Wood, and J.D. Stein. 2009. Aerially applied methylcyclohexenone-releasing flakes protect Pseudotsuga menziesii stands from attack by Dendroctonus pseudotsugae. For. Ecol. Manage. 257: 1231-1236.

Kamm, J.A., and R.G. Buttery. 1984. Root volatile components of red clover: Identification and bioassay with the clover root borer. Environmental Entomology 13: 1427-1430.

Ortega, F., R. Galdames, P. Soto, N. Teuber, A. Torres, and J. Levio. 2012. Avances en el mejoramiento genético del trébol rosado (Trifolium pratense L.) en Chile. $63^{\circ}$ Congreso Agronómico, Temuco, Chile (Abstract). 318 pp.
Palma, R., A. Mutis, L. Manosalva, R. Ceballos, and A. Quiroz. 2012. Behavioral and electrophysiological responses of Hylastinus obscurus to volatiles released from the roots of Trifolium pratense L. Journal of Soil Science and Plant Nutrition 12, 183-193.

Quiroz, A., F. Ortega, C. Ramirez, L. J. Wadhams, and K. Pinilla. 2005. Response of the beetle Hylastinus obscurus Marsham (Coleoptera: Scolytidae) to red clover (Trifolium pratense L.) volatiles in a laboratory olfactometer. Environmental Entomology 34: 690-695.

Steiner, J., and S. Alderman. 2003. Red clover seed production. VI. Effect and economic of soil $\mathrm{pH}$ adjusted by lime application. Crop Science 43: 624-630.

Tapia, S., F. Pardo, F. Perich, and A. Quiroz. 2005. Clover root borer Hylastinus obscurus (Marsham) (Coleoptera: Scolytidae) has no preference for volatiles from root extracts of disease infected red clover. Acta Agric. Scand. Sect. B Soil Plant Sci. 55: 158-160.

Tapia, T., F. Perich, F. Pardo, G. Palma, and A. Quiroz. 2007. Identification of volatiles from differently aged red clover (Trifolium pratense) root extracts and behavioural responses of clover root borer (Hylastinus obscurus) (Marsham) (Coleoptera: Scolytidae) to them. Biochem. Syst. Ecol. 35: 61-67.

Valdés, E., M.L. Aldana, B.R. Figueroa, O.M. Gutiérrez, R.M. Hernández, and T. Chavela. 2005. Trapping of Scyphophorus acupunctatus (Coleoptera: Curculionidae) with two natural baits in a field of Polianthes tuberosa (Liliales: Agavaceae) in the State of Morelos, Mexico. Florida Entomologist 88: 281-340.

Vrkočová, P., I. Valterová, J. Vrkoč, and B. Koutek. 2000. Volatiles released from oak, a host tree for the bark beetle Scolytus intricatus. Biochemical Systematics and Ecology 28: 933-947. 